\title{
Double Burden of Married Women Academician in Three Public Universities of Ethiopia
}

\author{
Blen Telayneh \\ Mekelle University, Department of Anthropology
}

\begin{abstract}
In developing country, predominantly in sub Saharan region the theme of development and women has emerged as a baseline for execution of any development output. In view of that, Ethiopian government is encouraging women to pursue in higher education and be part of economic development, alongside its movement for diminishing the existed socio-cultural attitude and practices that hinder women's participation and competition. As a result, little women have involved in education and few of them have joined the academic institutes with teaching and professional errands. In line with that, some women who are employed in those institutes are married and expected to work in multidimensional public and household career. That's why; this research is curious to assess the double burden of married academic women in neighborhood public Universities of Ethiopia, namely Mekelle, Adigrat and Axum. The researcher was interested to assess the academic, socio-economic contributions and challenges of married female university professors at academics and domestic level. To accomplish this study mixed research approach has been applied and ninety six female academicians had participated. In the finding 15 $\%$ of women are found as staff member but energetically participated in academics teaching, research, and community service, nonetheless there are natural and social factors which hinder them from fully occupied and contend in relative with male colleagues. Being married and mother of children is holding back their full involvement of academic role in different way. It is suggested that, unless the patriarchal structure of unbalanced gender role is changed, women employees will continue to suffer from double/triple burden and their contribution in education or other development aspect will be not worth mentioning.
\end{abstract}

Keywords: Women academicals, Marriage, Gender role, Academic work

DOI: $10.7176 / \mathrm{JAAS} / 56-07$

Publication date:June $30^{\text {th }} 2019$

\section{Introduction}

Gender division of labor refers to socially attributed responsibilities that are assigned for women and men. In this traditional division of labor, women are ascribed for a job that is generally assumed as unpaid care work i.e. household tasks. Those socially constructed obligations pretense a severe complication to women's labor force participation in public and other impacts on their survival and health (Emily and Brody, 2007).

Related with that, marriage is prominent social structures which unveil how division of labor and expected activities creates a burden on female. As a concept, Marriage refers to one of the most devotional and principal relationships between man and women (Bernard, 1984). In the globe, the traditional structure of marriage has been merely a union of a man and a woman, where a man contributes much of economic incomes and making every decision at home and public. Hitherto, the traditional pattern is being shifted due to industrial revolution and other economic crisis occurred in recent human history. Working woman are expected to balance their home base and public career, social tasks, personal life, and raising a family. As a result different researches and studies have discovered that married and working women from diverse socio-economic environment are showing assorted challenges on their health, emotion and experiences of working life as a result of dual burden (Hussain, 2009). With this circle, reports revealed that the greatest gap of labor force participation occurs between the ages of 25 and 49. The gap is expected, given that the intense domestic responsibilities do not allow women to enter and continue in formal wage labor force participation (International Labour Organization, 2007).

In line with that, earlier studies have showed that, the increasing of educated and working women in different public sphere is changing their gender role and social position, which also exposes them to face double burden. Marriage is believed to be a path of union by most of females societies but now a day's the so called " union " has changed and is moving to burdens, chiefly for educated working women (Khalid, 2014). For instance, due to the consequences of marriage burden, female professors at universities and colleges are not evenly distributed and tend to have fewer advanced degrees and lean in to huddle in the lower academic ranks, in the "softer" academic disciplines, at the less prestigious institutions with lower salary payment (Faia, 1977). In relation with the subject of women and development, researchers had been limited on exploring women's double burden from different social aspects and its impact on their health, performance, administrational position and disparities in educational sectors. Yet, there was unsatisfactory knowledge on how the double burden has become challenge on married and educated academic women in view of their expected contribution for family and public (academia). Married academician women are part of the development process and family formulation, which is key element of achieving the overall development goals. To accomplish this, education is a fundamental tool to empower 
women/men by improving their living standard. And it is the keystone for women's empowerment in different fields of endeavor. Education is the basic instrument that should be given to women in order to fulfill their role as full members of the soceity (UN, 2014). However, married women whether educated, working in the academics or not, there is double burden either at public or domestic level (Moghadam, 2015).

The principal assumption is that, educated women do have a choice to get married and have a family. Alongside, they can continue their contribution on socio-economic development of a country. But, by doing so, they risk their health, and limit their anticipated contributions due to the double burdens, and career prospects, since they are likely to complete domestic and public sphere responsibilities simultaneously. Besides, there is no detailed and profound research works on such crucial issues in Ethiopia so far. The intended study is designed to investigate the socio-economic and academic roles and related challenges of married women in three public universities of Ethiopia, located in Tigray regional state.

\section{Marriage and Gender Role}

Marriage is a contract made in due form of law, by which a free man and a free woman reciprocally engage to live with each other during their joint lives, which ought's to exist between husband and wife (Stewart, 2006). It is also contended that, marriage practices and gender roles are cultural traits that are strongly interlinked in most of human society. Gender roles are defined as different prospects that individuals/ groups perform as of their biological sex based on the values and beliefs of gender, in respect of their society. Gender roles, expectations and structure are described relatively in accordance with society's beliefs about sex's differences (Amy M, 2003). Traditionally, many societies used to believe that women have naturally determined nurturing behavior and womanly gender role often order them to behave in ways that implements nurturing. On the other hand, men are traditionally assumed to be leaders and hence develop masculine gender role as a heads of their households through their economic income and strong decisions made for the family. Gender roles can be linked with division of labour between males and females in realms of outside home including work places as well (Amy M, 2003). Men and women are customarily assumed to carry out different tasks and roles in work place as of their sex (Kanter, 1977).

Traditionally, martial gender roles are apparently attached with the wider culture of gender role (Ogletree, 2014). For instance, Gumuz one of Ethiopian society resident in southern region believes that, children must learn appropriate gender roles in accord with gender socialization goal of the society. Girls are expected to spend time with mothers to learn all household activities. In Gumuz society women during their toddler age, are socialized to be a good wife, cook, house keeper, and cleaner and to be polite and caring (Birhan, and Teka, 2018).

For much of the 20th century, the typical gender roles of marriage were clearly identified as a husband to be breadwinner and protector of the family, whereas a wife to be a good homemaker and mother. Even working woman had unspoken code about the domestic roles as a wife. Nevertheless, in the last two decades the overall economic and other socio-political changes had busted the traditional code of gender roles in marriage (Ogletree, 2014).

\section{Marriage and Education}

In a traditional marriage structure, education has been considered predominantly essential for men. This is because, men have been raised in social position where they are source of economic income and used to work in public and formal occupation which determines the socio-economic status of the family. For that reason, women had the tendency to select spouses with a better level of educational attainment (Dykstra \& Poortman, 2010). That is why; marriage arrangement is traditionally designed with distribution of gender explicit in the levels of education and economic status, till recent years. The fact is that, there are more educated men than educated women in the global population. But currently, there is an increasing percent of educated women, and the likelihoods of marriage pattern founding in relation with distribution of education has slightly reduced (Bavel, 2012). As a women attains higher education, their decision over marriage would be to find mate at list with the same or a higher level of educational status. In such kinds of marriage structure, the customary gender roles and the division of labor which has assigned male a major breadwinner and female as homemaker of the family model, has shifted since education has given women economic confidence (Blossfeld, 2009).

As claimed by micro-economic theory, the more women attain education and advance their status in the labor market; the reproduction costs increase. According to this theory, educated woman prefers to have less number of children than illiterate one. Having large number of children for educated women might influence their public careers; typically causes for the loss of foregone earnings and other career associated opportunities. The theory also suggests that, women's higher educational completion bring about a preference for developing quality lifestyle for nurturing children's. Thereby, highly educated women are required for reducing fertility, in the company of the increasing amount of expenses of children's persistent demand (Kalwij, 2006). Diffusionist perception regarding educated women argues that, educated women are usually regarded as trendsetters in family formation and relations (Salvini and Vignoli, 2011). This is a basically results of the need for strong dedication in which 
the labor market render educated women for stronger conflict and commitment between work and family life (Testa, 2012).

The other economic model of marriage presumes that women's employment is a threat of marital union due to the shifts of traditional gender roles within a couple. Conversely, in more recent years women have been increasingly presented in the labour market, but the negative effect of women's employment on marital stability has not been clearly identified (Livia and etal, 2014). These days, in modern societies, most decisions in marriage are done depending on the idea that satisfies the interests of couples to reduce disagreements. Regarding this, having similar education status and income generation means has smoothened understanding between the partners (Sigle-Rushton, 2010). Behind that, women's participation in different profession is a means to generate income, which would support couples to maintain a better living standard and minimize financial tension in marriage (RazYurovich, 2010). The globalization process and its overall impact on women empowerment, is likewise considerable in appraising women's education with its ultimate goal for creating employment opportunities. Alongside with that, through training and education, there are shifts on the previous gender norms of spouses in martial structure (Livia and etal , 2014).

\section{Education and Women in Ethiopia}

Ethiopia education history had been known by its religious foundation where the dominant attendant groups were males. Its basis has been spiritual doctrine that recommends religious training as sacred and must be delivered for male, those who used to be considered as purified in divine aspect. Modern education arrived in the country only at the beginning of the 20th century with slow progress in the consecutive academic years. Ethiopia's education system and procedures often used to be established by external individuals and education policies. Lack of qualified staffs in Ethiopia education system was a major problem that had been forcing the government to import teachers, administrators, and education advisors. But, in 1950, Addis Ababa University was established as the pioneer of higher education institute through the administration of western expatriates. It was only in the early 1970s that the Ethiopian higher education system designed in Ethiopian context (Sewnet, 2001).

With the slow development of modern education system in Ethiopia, elementary and primary schools had been given special concern in the past two and three decades. Urban areas of the country are found as foremost beneficiary of primary, secondary, and tertiary education, but most of rural communities are still in problem of accessing basic education, due to limited number of teachers and infrastructure problems that could facilitate education accessibility. The other problem is the gender disparities of education, along with all educational approachability challenges. Gender inequality, as a social structure and problem, aggravates the slow education progress occurrences with the existing beliefs on educating girls and boys. In the majority of rural area and few urban centers, girls are expected to get married earlier and their education or training is not considered as influential in their family and personal life. So, educating girls does not appeal rural family members, since their training is not supposed to have long term effect which could change the household and other public decisions (Yeshimebrat and Alemayehu, 2013).

The tertiary education system in Ethiopia is still in rigorous constrictions. Tertiary and university education in Ethiopia remains exclusive and where usually urban communities have the opportunity and few rural peoples attend with different a socio economic challenges. During the academic year of 2017-18, there were over 18 million primaries, 1.8 million secondary students. In these academic years, nearly 500,000 undergraduate students were attendants of higher education. In line with that, gender equality in education declines as student passes the next ladder. Though, the western world favor more females' than male to attend territory level education, in Ethiopian females comprises only 27 percent of the university population, and tragically quarter of them drop out before graduation (Asfaw, 2012).

It is said that, women education do not only promote the existence of one individual. Educating women are likely to change the family structure, and produce qualified family members that can be an input for several socioeconomic endeavors (Bhat, 2015). It is also argued that, educated women can also help in the reduction of infant mortality rate and build better reproduction health care and system. Overall, for the developing country, female education has become a vital path for poverty reduction (Kindiki and Syomwene, 2015). However, over the last decades, Ethiopian education has become an issue of critical analysis, where the gender gap frequency is high at universities. Moreover, female's instructor's entrance in university is less signified and their contribution in academic sphere is found as seldom important (Yeshimebrat, Alemayehu and Firew, 2013).

Along with that, the leading portions of illiterate people in Ethiopian are women, where the situation gets dangerous in rural areas. The enrolment ratio of female students at primary school is $29 \%$, secondary school $28 \%$, and tertiary level only1 $8 \%$ which is at the lowest standard. The wider educational disparity of women in Ethiopian regions shows disproportional of education access at overall national level. There exists wider gender based educational disparity among rural and urban areas in the same region. The general enrolment proportion and net enrolment ratio of women students in rural areas is lower than urban areas in the entire levels of education. As a result, girls in Ethiopian have fewer entrees to education than male students. Bearing in mind, that there exists low 
level of women enrolment at primary and secondary school education level, females' enrolment significantly deteriorate as one move up to higher levels of learning (Sewnet, 2001).

In similar with male, women academicians are roots of each profession. Usually, it is understood that they have a vital share in the execution of educational goals and inclusive development in developing nations (Hagos, 2015). Women's academician actual role in social support of female student's problem alongside with predominant societal norms is visible as well (Almaz, 2003).

\section{Research Methodology and Instrument}

In this research qualitative and quantitative research design has been employed. A primary and secondary source of data has been used to facilitate the data collection procedures. The current study applied in-depth interview, focus group discussion and survey data collection methods and instruments. To gather quantitative information, survey method has been executed. Final research results have been analyzed based on thematic analysis method to explore and interpret qualitative data. The quantitative data are analyzed using Statistical Package for Social Scientists (SPSS) Software updated version 16.0 for windows and Microsoft office excel was used in need of charts or table presentations.

\section{Finding and Discussion}

\section{Who are the informants?}

At the beginning of this study married academician women are the central focus of the researcher. Hence, women had been active informants in quantitative data collection periods and few men were participant during qualitative data collection processes. The researcher has tried to get informants from the selected universities in proportional way. In the study all informants are married and requited at different universities found in Tigray regional state. Majority of them are orthodox Christian religion follower and found in the age range of 25 - 40. Majority of them have few years of academic work experience consisting of minimum of 1 and maximum of 15 years, and few women not more than 15 in numbers, are $\mathrm{PhD}$ degree holder from all three universities. Basically, during the past government regimes women participation in academic was very low, and can be measured at zero level. Even women never been actively joining the academic profession as instructors, rather very few were attaining the higher education with the maximum level of secondary school. Then after, their college attainment is not much considerable. But, the current situation may reflect the change that was not appearing in the previous academic eras. The doors are now days open for women who are interested and capable of participating in the academic area. Here under, the setback of women success in education still existed in socio- cultural foundation and the general poverty related problem at large. Saying that, the promising but diminutive opportunity of education which is established by the government, is playing a great role for urban women to excessively involve in teaching and learning process in the universities, as the same as male academicians.

Most of the informants are married and have children. There are also women who are expecting babies during the time of data collection. In general most of them have 2- 5 children at average. Their perception regarding having a child is very important. In particular, academic women aged between 30 and 35 believes that, having children is very crucial for their martial stability, and to receive social appreciation. Having a baby is a natural blessing, and if they do not do it at the right age, they fear that the natural reproduction chances might be disappeared in the later age, and all the personal satisfaction of living in this world could be vanished. Thus, academic women, whether educated, professional or independent in variety of cases, till this day they are stacked on the status quo of the need of natural reproduction and social roles that exposes for burdens, and eventually costs for weakening of their academic performance.

It could be absurd to consider that married women and men academician status and role could be proportional, which cannot be measure and conclude in normal situation by neglecting other socially made women's gender roles. The married academicals women consider misalliance marriage and family structure as an outcome of traditional division of labor and patriarchal social structure. In the family structure, women and men responsibility, role, perception and expectations are presented aside differently. This situation became complex as academic woman are exposed for the family burden and roles, beside their public work. Meanwhile, men are prominent working figure at public and educational institutes. The problem goes with the male partners of women academicians that they did not change their traditional division of labor at home level. They still believe that, whether educated, academician or other professional, wives are expected to cover all domestic responsibilities. The burdens broaden as the babies are born and extra family caring is needed. While trying to satisfy the public work, social and domestic expectations, some women academician loses the required concentration to prepare themselves for class, to read and write different paper works. When the burden goes harder as the number of children increase, there are coincidences of leaving the academic area after getting married. In the table below, it is shown that in the selected three universities, sex ratio of working women and male academicians is not proportional. In particular at MA/ MSc, and $\mathrm{PhD}$ level, women academician presentation is very low. The more tragedy issue is not only the minimum number of female academicians, rather the study field that is stereotypically 
dominated by women at the university level. Most of them are enrolled in social science and humanity field of study, and men are found a dominant group in the hard/natural science profession. This is due to the factor that, women's position in the society has always been inclined with something that is effortlessly achievable, in a way that cannot take their full time and commitment.

Table one: Profile of active academicals based on sex ratio in three public universities of Ethiopia

\begin{tabular}{|l|l|c|c|c|}
\hline Name of university & \multirow{2}{*}{ Educational level } & \multicolumn{2}{|c|}{ Sex } & \multirow{2}{*}{ Total } \\
\cline { 2 - 5 } & & $\mathrm{M}$ & $\mathrm{F}$ & \\
\hline \multirow{4}{*}{ Mekelle } & $\mathrm{BA}$ & 337 & 156 & 493 \\
\cline { 2 - 5 } & MA/ MSc & 843 & 130 & 973 \\
\cline { 2 - 5 } & PhD and above & 181 & 13 & 194 \\
\cline { 2 - 5 } & Total & 1361 & 296 & 1657 \\
\hline \multirow{4}{*}{ Axum } & BA & 198 & 37 & 235 \\
\cline { 2 - 5 } & MA/ MSc & 385 & 39 & 424 \\
\cline { 2 - 5 } & PhD and above & 25 & 1 & 26 \\
\cline { 2 - 5 } & Total & 608 & 77 & 685 \\
\hline \multirow{5}{*}{ Adigrat } & BA & 183 & 34 & 217 \\
\cline { 2 - 5 } & MA/ MSc & 256 & 30 & 286 \\
\cline { 2 - 5 } & PhD and above & 18 & 1 & 19 \\
\cline { 2 - 5 } & Total & 457 & 65 & 522 \\
\hline
\end{tabular}

Source: Universities report for 2018 academic year

Socially women have been treated as mentally incapable of comprehending hard science theories or ideas. But, the problem is lack of provided opportunities and supports to take time for studies through minimizing home base tasks. In addition to that, women public gender role assigns them to domain relatively easygoing fields of study, such as secretary, geography, history, sociology, journalism and other social science related profession. At family level, women's life fortune were also found as to be mother, and good wife, thus, her engagement in hard science is not considerably important and spent most of their time to manage the responsibility of marriage. There is also a social believe that highly educated women may interfere in the decision of her marriage and challenge her husband, so that she will not be submissive women. So, educated women is only valued at public and politicized by the government and policies, but practically the society still have a fear regarding women education in challenging and breaking out the power relation between women and men, as well as in the family structure. Of course, there are emerging of highly educated women and instigation of feminist movement is awakening the government and the cultural trends regarding women's right and violence's they face in legal aspects.

The other table presented in below shows the sex ratio of academicians in their allocation for further education, which consequently drive a substantial contribution to increase the number of women academicians, with their parallel influence for education sector and other country wide socio - economic development. The sex ratio representation of educational study allocation hitherto seems unequal gender distribution, but comparatively there would be more highly educated women than the previous years in the prospect education system. Presently, the number of women academicians is not proportional and equally distributed, due to the low market of educated women during the recruitment periods of university professors. There are also key factors for small number of educated women at university level. One is the communities perception regarding women education, considering it insignificant and factor for marriage instability as a wife develop a decision making power though logical points of view and in a way that could develop for further women right issues. Secondly, the sexual harassment that female faces staring form home, elementary school and universities. Thirdly, traditional practices such as early marriage, Female gentile mutilation and related reproductive health problem, and finally female gender role do not allow succeeding of schools, since they lack sufficient time for study and other courses of education. In general, the socio-cultural perception of gender stereotype on women public engagement and assigned gender role has affected women's involvement and advancement in education sector, unambiguously at territory level. 
Table 2: Sex ratios of academicians on study leave in three public universities of Ethiopia

\begin{tabular}{|c|c|c|c|c|}
\hline \multirow[t]{2}{*}{ Name of university } & \multirow[t]{2}{*}{ Education level } & \multicolumn{2}{|c|}{ Sex } & \multirow[t]{2}{*}{ Total } \\
\hline & & $\mathrm{M}$ & $\mathrm{F}$ & \\
\hline \multirow[t]{3}{*}{ Mekelle } & $\mathrm{MA} / \mathrm{MSc}$ & 314 & 192 & 506 \\
\hline & $\mathrm{PhD}$ & 259 & 28 & 287 \\
\hline & Total & 573 & 220 & 793 \\
\hline \multirow[t]{4}{*}{ Axum } & MA/MSc & 378 & 52 & 430 \\
\hline & $\mathrm{PhD}$ & 162 & 7 & 169 \\
\hline & Specialization & 60 & 1 & 61 \\
\hline & Total & 600 & 60 & 660 \\
\hline \multirow[t]{3}{*}{ Adigrat } & $\mathrm{MA} / \mathrm{MSc}$ & 211 & 34 & 245 \\
\hline & $\mathrm{PhD}$ & 43 & 8 & 51 \\
\hline & Total & 254 & 42 & 296 \\
\hline
\end{tabular}

Source: Universities report for 2018 academic year

\section{Domestic Role of Female Academicians}

In the world history, women had been primarily responsible for different domestic activities. This trend was common since the time of forager and horticulturalist society, where the power relation between women and men were less essential. In the later human societies, with the expansion of agricultural land and most recently industrialization has brought about the need for power relation in control of land and other properties in accumulation of wealth. Through those processes, women were left behind for nurturing activity mainly domestic works. In the same way academic women in the selected public universities, distinctively married are expected to involve in home base tasks. To accomplish the household responsibilities most of them spend almost 5-10 hours in a day, which has also empirical impact on their professional carriers. Particularly, preparing kids for school is the most time taking task that can be equivalent with a given public extra work. As they get tired, while taking care of those activities, they loosely have adequate moment to upgrade their academic status, to read and focus on their academic matters. Moreover, lack of modern housing structure, cooking materials, cleaning equipments and shortage of water accessibility forced them to accomplish all the domestic works in labor intensive and more time consuming manner.

Academic women often manage all the domestic activities and academic works simultaneously. Mostly, they use the night time to read or write paper and other academic works. But this is not as easy as it is said. They faced sleep disorder and tiresomeness during the day time, while teaching in the class or running domestic works. The maximum sleeping hour for those women is five hour. Basically, any individual should get enough sleeping hour to be effective and successful in any profession, and uniquely, the academic field needs a stable mind to understand, to argue and to be rational of what's so ever is the idea.

The expected impact of domestic work affects women academicals status and position in their respective departments. The impact goes with holding administrative position and usually the cultural background and martial gender role of women academicians also affects their interest in holding higher status of administration. This had strong link with their childhood gender socialization that prone them to hold feminine character usually limited for domestic works. Though, some behavior and characters of women role are changed, still married academic women are in difficulty to demolish the home base gender role and embrace the public administrative position. There is also institutional challenge which creates gender base administrational participation gap and discourage female academicians to be active in leadership chore. From the studied university under this small research, three of them are managed by men presidents and most key managerial components are dominated by male. Even if there exists announcement for administrational position such as vice presidentship, directorship, research and community service headship, there are seldom women applicants. Most of them are afraid of failure on their leadership due to associated double burden to manage the domestic and public responsibilities. The problem is that, in patriarchal society particularly at institute level, whenever women's failure occurred in any issue, it is often been considered as solely result of their biological nature of sex and inferior level of women mental development and leadership inabilities. The allied reproduction difficulties and related home base responsibilities never been valued and considered as a barrier to be successful in accomplishment of leadership role at public sphere. There are major factors for unequal gender leadership position in the study university. The first is the attitude of men colleagues and managers toward the leadership potential of women staffs. Most of men colleagues believe that women have natural reproduction function and it has arranged them to be good at nurturing related home base activities. Secondly, women academician lack leadership and management experience due to their hectic and high domestic responsibility. Even if the university arranges a training sessions for personal development of staff members, only men and few bachelor women are beneficial. Married women rather use each spare time for taking care of their family and accomplish uncompleted domestic and social chores. There is also a condition that they 
face sexism nuisance from male colleagues, if they fulfill the criteria and hold administrational work. Sometime, male colleagues perceive women's leadership position only as an element of country wide strategy, just to realize the principle of gender equality and thus women became leader due to affirmative action than their potential of management role. Those few academician women who hold lower and middle level managerial role, there are cases where their decisions might not be influential, not because the declared ideas are not important but barely because they are female. In fact, this is anticipated from a patriarchal country like Ethiopia, whereas most public issues are decided and managed by androcentric ideas. Thus, if male academic colleagues are born and raised in this community, perhaps they are socialized with the structure where women's leadership and decision is underestimated and their perception regarding female staff leadership is reflection of their socio-cultural experience. The only adequate leadership position of women academician in the universities is gender focal person, considering it as female's issues. Beside, male are not usually interested in the position, thinking gender as merely the problem and issue of females. Even there are male staff members who consider gender issue as barely women's subject matter, thus it must be run by the concerned personnel.

In line with their domestic and academic responsibility, women professors face mental burdens, while accomplishing the academic and domestic works. As of the day their first baby arrived, there has been motherhood fears and hormonal complication. Children are now the major responsibility of women and raising them has a challenge, especially for new mothers. In previous years there was extended family structure and babies have been the responsibilities of mother, sister, grandmother and other female relatives, who used to live in a house. Even, there were neighborhood supports if there is any personal problem which hinder from looking after of children. But, the current family structure which is in transitional period is more likely nuclear type and independent in managing household issues. As a result, women are forced to perform all domestic matters without others support.

\section{Impacts of Domestic Responsibility on Academic Sphere}

Marital status is a key factor for academic women's incompetency with male colleagues. Along with that, the socially constructed martial gender role has a great impact on their attitude and activities as a professional in different field. Though, marriage is one of socially valued phenomena in human being, there are matrimony linked socially constructed life expectations that lead women to be in subordinated position at home and public. There are reproduction role that lead them to be more emotional and carrying for the family members, and this will affect their public spheres, in particular the academic field need convenient time and focus. But, female academicals spend their wider time at home than public issues, after marriage.

Nonetheless, the participation of married female academician is increasing from the previous years; their status in administration position is very low. There are few women who hold the positions of quality assurance, gender officers and head department, but they are not enrolled in higher level of administrational tasks. Working at home for different purposes is affecting their contribution at universities. In particular, women with large number of children and family members face the difficulty, which eventually minimize their academic linked contribution at their respective universities. There is visible potential and commitment difference between married women, married men and bachelor women and men. This conduction is also affecting married academician women's paper publication and research role, since they are mostly attached with double burden due to home and public responsibilities. Besides, women academic rank, working position, and decision making abilities are limited due to home base burdens, in view of that the access to information is limited and lack of skill related capabilities. There is also a situation that higher education opportunities, short trainings, educational conference attainment has become solitary the chance of single women and male academicals.

Saying all that, the existing gender role, which is on the process of transformation due to external and internal factors, needs to be focused and seen on revolution of the central element of the social structure that divides power and labor between men and women in martial relation. In particular, family members have to be active at home level responsibilities and shared working lifestyle must exist. At university level there is a need for establishment of baby daycare centers and services, to support and turn women academician more concentrated and committed during work time. An awareness regarding home base gender related challenges and its impact on education and overall socio-economic development should be arranged at university level, in particularly men must be learned how to be sensitive in sharing the kitchen burdens. Unless, women academician participation would be only counting of number and the expected academic contributions cannot be achieved, and the overall country wide educational and human development goals cannot be realized.

\section{Economical State of Married Academic Women}

Economic state of academic women was other intention of this small scale research. From the data the economic state can be seen in different level, first as income generation means at personal level and secondly women's economic contribution at university level. Working at university as instructor and professionals gives them a great proud and credit from the academic communities and society. In most areas, women have been countering continual challenges to join and requite as instructor at university due to various socio-cultural perception and 
economic challenges. As a consequences gender disparity at territory education was found as a key setback for disproportional allocation of women instructors in public university. But, for the few women, working at university is superior prospect as source of income generation means; few also engage in granted research and community service works, which provide them additional income generation opportunity. But, still their problem is that, all incomes are consumed for household issues including payment for house rent and kid's school, and daily consumption material and other basic family needs. Besides, there are incidents that husbands and family members decide on the utilization of their income. On the other hand, comparing other women in another profession, academic women were found more confident and economically independent, which offers them a right on utilizing of salary for personal needs.

The other is the contribution of women academicians for their respective university in participating, creating external linkage and income generation means for diverse academic activities such as research and conferences preparation. Seeing that, the number of women's participation is very low; their economic contribution in creating means of income from external body is very rare. The low skill and knowledge of women of academician in using computer technologies, lack of awareness about known academic organization and linkages, are attributed factors for the gap. This condition is also aggravated by the home base responsibilities which hinder them from assigning enough time in accessing updated and new information. Basically, academician women's are enhanced on using technologies comparing with other women who are engage in other professions.

Women, in the studied universities manage their income in different saving methods. Traditional saving method $i q u b^{1}$ is used by the majority. This traditional money saving system is used by collecting and collective individuals from their family, colleagues, and neighbors. The other method for saving money is via formal bank, and universities have an organized money saving system. The money which is gained from these ways are consumed for diverse purposes like buying home furniture's and objects, spending for other business works, and building a home.

\section{Academic Contribution and Challenges}

Different studies and findings have indicated that women have a great contribution in academic area, if opportunities and education accesses are given. Meanwhile, in this study, since it was conducted in developing country, women academicians, particularly married are not significantly contributing much enough in academic domains. When we see the précised roles of married academicians, most of them are engaged in regular teaching and learning activities. Only few women are participant in publishing paper works, research, and community services, which are additional, but significant tasks that one can contribute at university level. In particular, the presence of married women at academic administration and higher management as a role is rare. Even though, some academic women are capable of managerial and administration tasks, the position is not given due to the fear and reality that the home base responsibility might be an obstacle to perform. They are not even interested in computing for such position with the stereotype of gender roles which assigned women in domestic tasks. The challenges that academic women faces while participating in the academic are also discussed in detail as the following.

Socio-Economic Challenges: Due to lack of proper budget allocation and utilization, there exist poor office facilities and academic services of university which creates unpleasant working environment for teachers. This has also intended for the growth of deprived perception of student against instructors in general, and consequently, it leads communities to loss social respects for instructors. In addition to the weakness of the overall structure of education system in the country in generating productive skilled human power, the low salary attributed for instructors, has dismissed the previous prestigious profession of teaching in the society. Under this pine, community's perception toward women's academician is relatively better than male, but all the financial challenges have forced them to be in deprived professional position. Student's perception for female instructors is unappealing. There is also a state that women academicians faces sexual harassments from male students, whether they are married, senior or highly educated. They are also blamed for lack of technological, pedagogical skills and English language deficiency while teaching in the class. The problem broadens for married women, as they prone to handle all the household and academic responsibilities, where they lack enough time for personal and skill related development. Married female instructors hold larger risk of works in family matters than single women (Acheampong, 2013). In addition, the societies including students have negative attitudes towards married women academician's public roles and their capacities while performing a tough profession. The society and students believes that women are likely incompetent to perform and fail to flourish in the teaching profession just because of their biological sex. Such kind of approach entails squat trust of the community in women's ability to achieve

\footnotetext{
${ }^{1}$ iqqub regarded as a form of traditional savings association in which weekly or monthly payments of a fixed sum are exchanged for the privilege of receiving a large sum at some point in the life of the group. It can be goes with the type of traditional financial institutions which are included under savings associations. These descriptions suggest that the iqqub is a savings association where each member agrees to pay periodically a small sum into a common pool so that each, in rotation, can receive one large sum (Dejene Aredo, 1993).
} 
everything at public, which eventually shrink their confidence on involvement of public issue and then, set themselves in the domestic task.

Personal Challenges: Married academic women faces anxiety and stress since they are subjected for multiple work related difficulties than male colleagues. The stress of academic women goes with the homework interfaces which are stereotypically prearranged as gender role in which power and self-determination are not traditionally assigned to women. An academic woman also faces functional inconsistency between the workplace and the home. Married women academicians also lack self-assurance thinking that they cannot be terrific teachers till they received a higher educational level such as master's and doctoral degrees.

Skill Related Challenges: Married women academicians in the universities are often isolated, because of their low contacts with male casual networks. Besides, most of married academicians have low level of grouping with other female staffs. This has an impact on their access to information on divers of issues, including scholarships and research projects that would advance their instructive proficiency. Married academician women face the skill related gap of using technology as well. This affects their role in digital and online learning services. The other challenge is using computers in a way that could help them to download different educational materials and update themselves in different aspects. Usually, they ask and gain a support from male colleagues. But, the extreme dilemma is that, women academician were found as reluctant and shy to use and access every parts of computer materials, that they have been culturally learned to be passive and dutiful for the new inquires, especially for the materials that are socially used to be assigned only male's object. Most married women academician also faces shortage of training in teaching pedagogy. This training would provide the skill of articulating theoretical aspects of a given field of study with practices, and support them to be clear and explicable while coaching students. The selected studied public universities do have a short term trainings of pedagogy skill for beginner academicians. But, married women were found as disinclined to participate in the training, rather they would prefer to use their extra time for family care. In addition, most of them do not like the pedagogy training entitled as "higher diploma program" due its exhausting and time consuming class behavior, and if there is change on its delivery method, they have a curiosity to improve their teaching skill through as such empowerment activities.

\section{Societal Contribution of Married Women Academician}

The value of education has been accepted by various international and national organizations. And, globally education has become the quest of basic human right and its contribution to bring about individual equality, harmony and other socio-economic development are its instant visible role among the society. As a member of a society and backbone of the family, women's education has vital role in various aspects of social development. Simultaneously, married academic women in the studied public universities of Ethiopia do have a multidimensional contribution for the development of their family, and society, besides their personal contentment and advancement. Socially, academic women plays significant role in assuring women's right and they are capable of providing a better policy implications for different nationwide strategies through their research works and dissemination. Educated women do have the experience of reading and questioning toward the whole activities around them, with wider thoughts. So, they often question the reason for unequal presentation and quest for the augmentation of equal opportunities of women and other marginalized groups in various socio-cultural matters. The long term benefits provided by married women academician are evident at family levels.

Women academicians' educational level directly affects the education accomplishment of their children and society as well. Women academicians are found as important individual in challenging the particular gender roles and other bad cultural practices of society. It was also found that women academician do have a better access for information through reading internet and other materials which provides them with better health understanding for family, children and themselves. Being highly educated also gave them a better and relatively privileged job opportunity as well as public trust in the society. Regarding the economic security of married academician, women had gained essential social value which let them to slightly develop power over household decisions than the other community members of women. In addition to that, women academicians at university level play a vital role in supporting female students in different aspects. First, they are a mentionable role-model for female students to continue and succeed in the overall challenges of university education. Secondly, most of them are involved in consulting and sharing life experiences that possibly will guide female students in the right track of educational life. And lastly, few academician women who hold gender focal personnel positions are dealing with reduction of sexual harassment incidences and they often encourage female students to report for the concerned body if any case has occurred.

In spite of the above discussion, there are many barriers that decreases married academic women from contributing much more in social development at their higher educational standard. Though, the community prefer to have educated women, still the perception of society does not allow girls for higher education attainment and rather there is prioritization of every public resources for boys. Married academic women face many problems and 
leave their teaching profession sooner due to different social and cultural factors. Married women are supposed to look after the house and children instead of pursuing for future studies and personal development trainings. There are also female academician whose movement outside their homes is controlled by their parents and husbands, which forced them to leave the university teaching profession. Most of the married academic women are interested to pursue higher education even after marriage. But, they have some worries regarding safety and security problems while travelling abroad to attend any training or further study. Critically, nature-culture based child rearing responsibilities have forced them to suppress from the expected societal contribution as highly educated members of the community.

Acknowledgment: I thank the Department of Anthropology, Mekelle University for the financial support to accomplish this study. In addition, I would like to pass my acknowledgment for Mekelle, Adigrat and Axum university women staff members for their willingness and informantion during study.

\section{References}

[1] Emily Esplen and AlysonBrody. (2007). Putting Gender Back in the Picture: Rethinking Women's Economic Empowerment. Report prepared at the request of the Swedish International Development Cooperation Agency (Sida), Institute of Development Studies, and Un.

[2] Acheampong, A. (2013). An investigation into work-life balance practices and its effect on career progression. School of Business, knust.

[3] Almaz, E. (2003). Women in faculties of teacher training institutions in Ethiopia. UNESCO International Institute for Capacity Building in Africa, Addis Ababa.

[4] Amy M, B. (2003). Gender roles and society. ABC-CLIO publisher .

[5] Asfaw, A. (2012). Gender Inequalities in Tertiary Education in Ethiopia: Mediating the Transition to University through the Development of Adaptive Competencies, Global Scholars Program Working Paper Series.

[6] Bavel, J. V. (2012). The reversal of gender inequality in education, union formation and fertility in Europe. Vienna Yearbook of population Research, 10, 127-154.

[7] Bhat. (2015). Role of education in the empowerment of women in India. Journal of Education and Practice. Vol.6, No.10, ISSN 2222-288X.

[8] Birhan Wohabie, and Teka Zewdie. (2018). Marriage practices and gender role socialization among the Gumuz of Ethiopia. African Journal of History and Culture 10, no. 4, 51-56.

[9] Blossfeld, H.-P. (2009). Educational assortative marriage in comparative perspective. Annual Review of Sociology, 35, 513-530.

[10] Dejene Aredo. (1993). The Informal And Semi- Formal Financial Sectors In Ethiopia: A Study Of The Iqqub, Iddir, And Savings And Credit Co-Operatives. AERC Research Paper Series, Nairobi, Kenya.

[11]Dykstra, P.A., \& Poortman, A-R. . (2010). Economic resources and remaining single: trends over time. . European Sociological Review, 26(3), 277-290.

[12] Hagos, Kiros. (2015). Occupational stress among secondary school teachers and their coping strategies: The case of central zone of Tigray region. International Journal of Academic Research in Education and Review. Vol. 3 (6).

[13] Hussain, I. (2009). Problems of working women in Karachi, Pakistan. Cambridge Scholars Publishing.

[14] International Labour Organization, \&. I.-G. (2007). Equality at Work: Tackling the Challenges: Global Report Under the Follow-up to the ILO Declaration on Fundamental Principles and Rights at Work (Vol. 1). International labour force organization .

[15] J.Bernard. (1984). Work and family: Changing roles of men and women. Palo Alto, CA: Mayfield.

[16]K., M. (2014). Human development report 2014: Sustaining human progress: Reducing vulnerabilities and building resilience. United Nations Development Programme, New York.

[17] Kalwij, A. (. (2006). Education and postponement of maternity: Economic analyses for industrialized countries. Berlin: Springer.

[18] Kanter, R. M. (1977). Men and women of the corporation Basic Books. New York.

[19] Kindiki and Syomwene . (2015). Women education and economic development in Kenya: implications for curriculum development and implementation processes. Journal of Education and Practice Vol.6, No.15, ISSN 2222-288X.

[20] Livia Sz. Oláh, Rudolf Richter and Irena E. Kotowska . (2014). State of the art of reports, “The new roles of men and women and implications for families and societies". Family and working paper serious.

[21]M. A, F. (1977). Discrimination and exchange: The double burden of the female academic. Pacific Sociological Review, 20(1), 3-20.

[22] M.Moghadam, V. (2015). Women, work and family in the Arab region: Toward economic citizenship. . DIFI Family Research and Proceedings, 7. 
[23] Myriam, B. (2008). "Export-oriented policies, women's work burden and human development in Mauritius.". Journal of Southern African Studies 34, no. 2: 239-253.

[24] Ogletree, S. M. (2014). Gender role attitudes and expectations for marriage. Journal of Research on Women and Gender 5, 71-82.

[25] Raz-Yurovich, L. (2010). Men's and women's economic activity and first marriage: Jews in Israel, $1987-$ 1995. Demographic Research, 22(29), 933-964.

[26] Salvini, S., Vignoli, D. (2011). Times change: Women's and men's marital disruption dynamics in Italy during a time of social transformations, 1970-2003. Demographic Research 24(5), 145-174.

[27] Sewnet Mamo. (2001). "Participation of Ethiopian Women in Education and Development". International Conference on African Development Archives. Paper 23.

[28] Sigle-Rushton, W. (2010). Men's Unpaid Work and Divorce: Reassessing Specialization and Trade in British Families. Feminist Economics, 16(2), 1-26.

[29] Stewart, M. N. (2006). Genderless Marriage, Institutional Realities, and Judicial Elision. Duke J. Const. L. \& Pub. Pol'y, 1, 1.

[30] Testa, M. R. (2012). Family sizes in Europe: Evidence from the 2011 Eurobarometer survey. European Demographic Research Papers No.2.

[31] United Nation. (2014). The Nairobi forward-looking strategies for the advancement of women. UN.

[32] Yeshimebrat Mersha , Alemayehu Bishaw and FirewTegegne. (2013). Factors affecting female students' academic achievement at Bahir Dar University. Journal of International Cooperation in Education, Vol.15 No.3. 